IRA-International Journal of Education \& Multidisciplinary Studies

ISSN 2455-2526; Vol.03, Issue 03 (2016)

Institute of Research Advances

http://research-advances.org/index.php/IJEMS

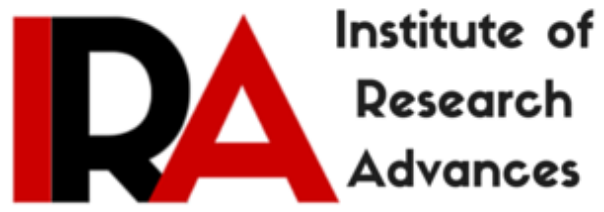

\title{
Students' Involvement in Campus Activities: Implications to Levels of Sociability
}

\author{
${ }^{1}$ Shirlyn L. Larupay \\ West Visayas State University-Janiuay Campus \\ Cabesa Jose D. Brana Street \\ Janiuay, Iloilo, Philippines. \\ ${ }^{2}$ Guiller P. Pendon \\ West Visayas State University-Janiuay Campus \\ Cabesa Jose D. Brana Street \\ Janiuay, Iloilo, Philippines.
}

DOI: http://dx.doi.org/10.21013/jems.v3.n3.p11

\section{How to cite this paper:}

Larupay, S., \& P. Pendon, G. (2016). Students' Involvement in Campus

Activities: Implications to Levels of Sociability. IRA International Journal of

Education and Multidisciplinary Studies (ISSN 2455-2526), 3(3).

doi:http://dx.doi.org/10.21013/jems.v3.n3.p11

(C) Institute of Research Advances

(cc) BY-NC

This works is licensed under a Creative Commons Attribution-Non Commercial 4.0 International License subject to proper citation to the publication source of the work.

Disclaimer: The scholarly papers as reviewed and published by the Institute of Research Advances (IRA) are the views and opinions of their respective authors and are not the views or opinions of the IRA. The IRA disclaims of any harm or loss caused due to the published content to any party. 


\begin{abstract}
Students' involvement and sociability in campus activities provide college students with ample opportunities to have a greater magnitude of student-to-student interactions. As such, they are more likely to perceive their educational experiences as having high quality compared to those of non-participants. This descriptive study utilized a sample of 300 students of WVSU-Janiuay Campus who were chosen through stratified purposive sampling. The results indicated that students often participated in campus activities. As to extent of involvement students are always involved in campus activities. The levels of sociability are very high as answered. As to campus activities that they participated in and levels of sociability significant difference existed while no significant differences existed in student's involvement in campus activities. There was a positive and significant relationship among campus activities that students participated in, extent of students' involvement and levels of sociability. Implications and recommendations for future research were discussed.
\end{abstract}

Keywords: Campus Activities, Implications, Levels of Sociability, Students’ Involvement

Participation with non-academic pursuits is not only beneficial to student development, but is known to be highly valued by teachers and staff. It may seem like a small change, but by demonstrating to students that we view these activities as equally important to academic study (Pascarella, et al, 2001).

Building an interactive campus is an integral component of universities' educational mission. Perhaps this vision is best characterized by an image of students, faculty, and staff helping one another day by day to cultivate aspirations, nurture commitments, and practice they profess.

Seen in this light, being part of the West Visayas State University (WVSU) system is not ultimately about personal gratification, "doing one's own thing," or peaceful co-existence, although WVSU-Janiuay is certainly an academe where its constituents can enjoy considerable freedoms, excel, and build lasting friendships by participating in various activities.

Research was performed on the claim of fact that students involved in extracurricular activities receive higher grades than those not involved in activities. This topic was studied because budget for school activities are meager, and the administrators of schools want to spend the money efficiently. This report examines the correlations among the activities that students participated in, extent of participation in campus activities, and levels of sociability.

A myriad of components contribute to the reasons why extracurricular activities benefit students academically. One of these reasons is that students learn character-building lessons that they can apply to their study habits and to their lives. Activities such as athletics, music, theater, and organizations teach students how to discipline themselves through drills, practices, or rehearsals (Astin, 1993). The students have a responsibility to the activity and must perform the tasks assigned to them whether it be to run, sing, act, or organize an event. By participating and persevering in any of these activities, the students gain a sense of self-respect, self-esteem, and self-confidence. Extracurricular activities give them pride in their accomplishments, and they learn that if an activity is worth doing, it is worth doing well.

Through extracurricular activities, students learn life skills that benefit their studies. Matt Craft, president of the Iowa State University Government of the Student Body, stated that being involved teaches students organization and time management skills. Because activities take time out of the students' schedules, the involved students must plan their time wisely and efficiently to complete the assigned tasks.

It is believed that given the right tools, students will thrive in taking charge of their own development, but to help them do this, we need to reassess our role as higher education providers. We should not just provide the opportunities for students to achieve good academic results but actively

Funded by West Visayas State University- Janiuay Campus 
promote the benefits of a wider curriculum to students. After all, university should be seen as a transformative experience through which students can prepare themselves to succeed in the many and varied roles they will undertake in future life (Trevino, 2002).

That's why, over the last few years, West Visayas State University-Janiuay Campus has not been into research on campus activities and levels of sociability and its importance and value of both academic curriculum and co-curricular activities in developing the range of skills and attributes that are important for graduates. Armed with a better sense of the student journey, the university has designed a development plan to support students' transition through independence and competencies in the future work and enable them to take responsibility for their own development.

This study aimed to assess the students' involvement in campus activities and its implications to levels of sociability:

Specifically, this study sought to answer the following questions:

1. How frequent do students participate in campus activities as an entire group and when classified as to sex, course and year level?

2. What are the extent of students' involvement in campus activities as an entire group and when taken classified as to sex, course and year level?

3. What are the levels of sociability in campus activities as entire group and when classified as to sex, course and year level?

4. Is there a significant difference in the campus activities that students participated in when classified as to sex, course and year level?

5. Is there a significant difference in the extent of students' involvement in campus activities when classified as to sex, course and year level?

6. Is there a significant difference in the levels of sociability in campus activities when classified as to sex, course and year level.

7. Is there significant relationship in the campus activities that students participated in, extent of students' involvement and levels of sociability?

\section{Methodology}

This study determined the students' involvement in campus activities and its implications to levels of sociability of West Visayas State University Janiuay Campus

It also aimed to ascertain whether the students' involvement in campus activities and its implications to levels of sociability could be influenced by personal factors.

Descriptive research involves gathering data events and then organizes, tabulates, depicts, and describes the data collection (Garcia, 2003).

The respondents of the study were the three hundred (300) students of West Visayas State University- Janiuay Campus. They were taken through stratified purposive sampling. As initial step, the researcher identified the respondents. Identification of respondents was based on sex, course and year level.

The researchers constructed a rating scale designed to determine the level of students' involvement in campus activities and its implications to levels of sociability.

The tentative draft of the questionnaires on students' involvement in campus activities was submitted for validation to panel of jurors who are expert in the field of student affairs. An adapted questionnaire from David, et al for levels of sociability.

After the questionnaire was revised and finalized, permission to conduct the study was secured from the campus administrator and the instrument was distributed to the respondents at West Visayas State University-Janiuay Campus. The researcher gathered the accomplished instruments as soon as the respondents finished answering them.

The data gathered were subjected to certain statistical analysis to determine the levels of students' involvement in campus activities and its implications to levels of sociability. 
In determining the responses of students in campus activities that they participated in the numerical weights and responses are as follows:

Scale of Mean

$3.21-4.00$

$2.51-3.20$

$1.76-2.50$

$1.00-1.75$
Description

Always

Often

Seldom

Never

In determining the results in extent of students' involvement in campus activities an arbitrary scale was used:

Scale of Mean

$3.21-4.00$

$2.51-3.20$

$1.76-2.50$

$1.00-1.75$
Description

Always

Often

Seldom

Never

In determining responses of levels of sociability this scale with its interpretation was used.

\begin{tabular}{|c|c|c|}
\hline Scale of Mean & Responses & Interpretation \\
\hline $3.21-4.00$ & Always & Very High \\
\hline $2.51-3.20$ & Often & High \\
\hline $1.76-2.50$ & Seldom & Low \\
\hline $1.00-1.75$ & Never & Very Low \\
\hline
\end{tabular}

Table 1

Distribution of the Respondents

\begin{tabular}{lll}
\hline Categories & $\mathrm{f}$ & $\%$ \\
\hline Entire & 300 & 100 \\
Sex & & \\
Male & 150 & 50 \\
Female & 150 & 50 \\
Course & & \\
BEED & 50 & 16.67 \\
BSED & 50 & 16.67 \\
BS Infotech & 50 & 16.67 \\
BSHRST & 50 & 16.67 \\
BSIT & 50 & 16.67 \\
BCM & 50 & 16.67 \\
Year Level & & \\
$1^{\text {st }}$ Year & 75 & 25 \\
$2^{\text {nd }}$ Year & 75 & 25 \\
$3^{\text {rd }}$ Year & 75 & 25 \\
$4^{\text {th }}$ Year & 75 & 25 \\
\hline
\end{tabular}




\section{Results and Discussion}

Table 2

Responses of the Students in Campus Activities that they Participated In

\begin{tabular}{lllll}
\hline Categories & No. of Respondents & Mean & Description & $\begin{array}{l}\text { Standard } \\
\text { Deviation }\end{array}$ \\
\hline Entire & 300 & 3.07 & Often & .67 \\
Sex & & & & \\
Male & 150 & 2.99 & Often & .65 \\
Female & 150 & 3.26 & Always & .52 \\
& & & & \\
Course & & & & .54 \\
BEED & 50 & 3.67 & Always & .50 \\
BSED & 50 & 3.50 & Always & .57 \\
BSInfotech & 50 & 2.79 & Often & .47 \\
BSHRST & 50 & 2.82 & Often & .50 \\
BSIT & 50 & 2.42 & Seldom & .54 \\
BCM & 50 & 3.23 & Always & \\
& & & & .50 \\
Year Level & & & Always & .72 \\
$1^{\text {st }}$ Year & 75 & 3.73 & Always & .48 \\
$2^{\text {nd }}$ Year & 75 & 3.41 & Seldom & .67 \\
$3^{\text {rd }}$ Year & 75 & 2.28 & Seldom & \\
$4^{\text {th }}$ Year & 75 & 2.61 &
\end{tabular}

Scale of Mean

$3.21-4.00$

$2.51-3.20$

$1.76-2.50$

$1.00-1.75$
Description

Always

Often

Seldom

Never

Table 3

Extent of Students' Involvement in Campus Activities

\begin{tabular}{lllll}
\hline Categories & No. of Respondents & Mean & Description & $\begin{array}{l}\text { Standard } \\
\text { Deviation }\end{array}$ \\
\hline $\begin{array}{llll}\text { Entire } \\
\text { Sex }\end{array}$ & 300 & 3.25 & Always & .05 \\
Male & 150 & 3.24 & Always & .05 \\
Female & 150 & 3.25 & Always & .05 \\
& & & & \\
Course & & & & .06 \\
BEED & 50 & 3.23 & Always & .05 \\
BSED & 50 & 3.25 & Always & .05 \\
BS Infotech & 50 & 3.25 & Always & .05 \\
BSHRST & 50 & 3.25 & Always & .05 \\
BSIT & 50 & 3.25 & Always
\end{tabular}


$\mathrm{BCM}$

50

3.36

Always

.04

Year Level

$1^{\text {st }}$ Year 75

$2^{\text {nd }}$ Year

$3^{\text {rd }}$ Year

75

$4^{\text {th }}$ Year

75

3.25

3.26

$\begin{array}{ll}\text { Always } & .06 \\ \text { Always } & .05 \\ \text { Always } & .05 \\ \text { Always } & .04\end{array}$

Scale of Mean

$$
\begin{gathered}
3.21-4.00 \\
2.51-3.20 \\
1.76-2.50 \\
1.00-1.75
\end{gathered}
$$

Table 4

Levels of Sociability

\section{Description}

Always

\begin{tabular}{|c|c|c|c|c|}
\hline Categories & No. of Respondents & Mean & Description & $\begin{array}{l}\text { Standard } \\
\text { Deviation }\end{array}$ \\
\hline Entire & 300 & 3.23 & Very High & .21 \\
\hline \multicolumn{5}{|l|}{ Sex } \\
\hline Male & 150 & 3.31 & Very High & .25 \\
\hline Female & 150 & 3.15 & High & .12 \\
\hline \multicolumn{5}{|l|}{ Course } \\
\hline BEED & 50 & 3.38 & Very High & .33 \\
\hline BSED & 50 & 3.33 & Very High & .27 \\
\hline BS Infotech & 50 & 3.22 & Very High & .05 \\
\hline BSHRST & 50 & 3.04 & High & .09 \\
\hline BSIT & 50 & 3.18 & High & .11 \\
\hline $\mathrm{BCM}$ & 50 & 3.23 & Very High & .06 \\
\hline \multicolumn{5}{|l|}{ Year Level } \\
\hline $1^{\text {st }}$ Year & 75 & 3.40 & Very High & .34 \\
\hline $2^{\text {nd }}$ Year & 75 & 3.22 & Very High & .05 \\
\hline $3^{\text {rd }}$ Year & 75 & 3.07 & High & .11 \\
\hline $4^{\text {th }}$ Year & 75 & 3.23 & Very High & .06 \\
\hline \multicolumn{2}{|c|}{ Scale of Mean } & ses & Interpretation & \\
\hline \multicolumn{2}{|c|}{$3.21-4.00$} & & Very High & \\
\hline \multirow{2}{*}{\multicolumn{2}{|c|}{$\begin{array}{l}2.51-3.20 \\
176-2.50\end{array}$}} & & High & \\
\hline & & & Low & \\
\hline \multicolumn{2}{|c|}{$\begin{array}{l}1.76-2.50 \\
1.00-1.75\end{array}$} & & Very Low & \\
\hline
\end{tabular}

Often

Seldom

Never 


\section{Inferential Data Analysis}

Table 5

Differences in the Responses of the Students in Campus Activities that they Participated In using t-Test

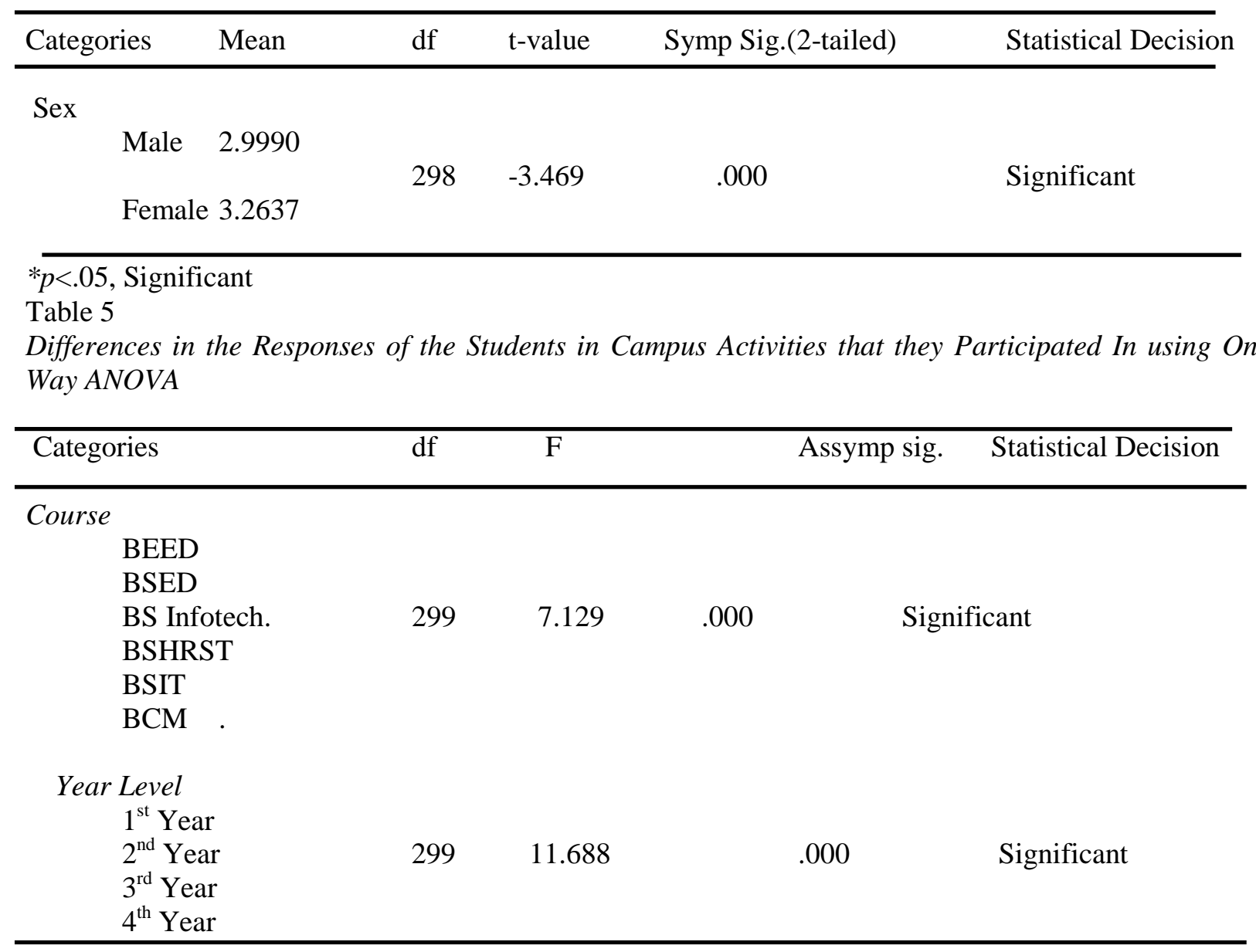

$*_{p}<.05$, Significant

Table 6

Differences in the Extent of Students' Involvement in Campus Activities using t-Test

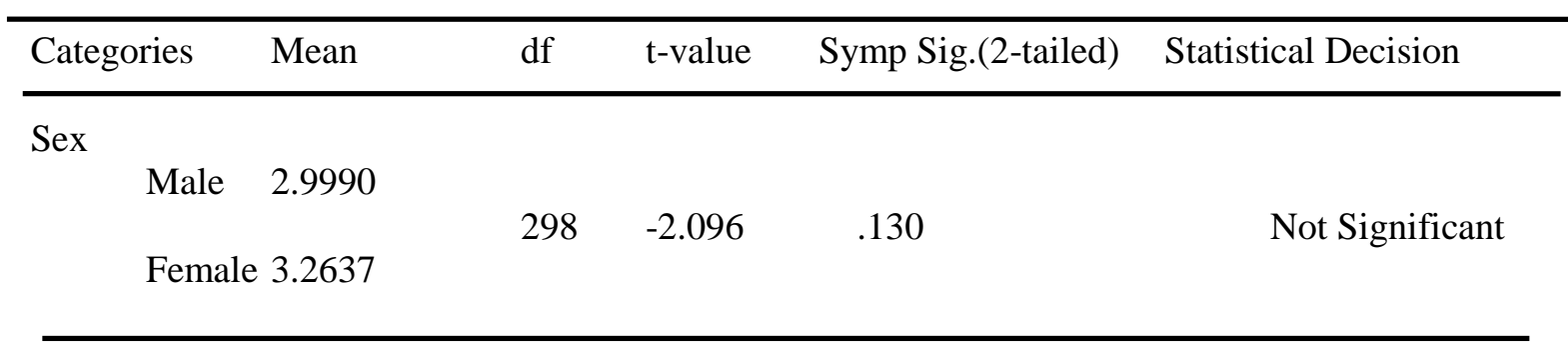

$* p>.05$, Not Significant 
Table 7

Differences in the Extent of Students' Involvement in Campus Activities using One-Way ANOVA

\begin{tabular}{lllll}
\hline Categories & df & F & Sig & Statistical Decision
\end{tabular}

Course

BEED

BSED

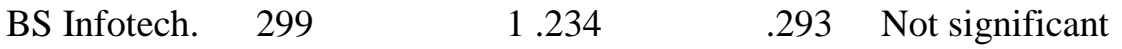

BSHRST

BSIT

BCM .

Year Level

$\begin{array}{lllll}1^{\text {st }} \text { Year } & & & & \\ 2^{\text {nd }} \text { Year } & 299 & 1.320 & .268 & \text { Not significant } \\ 3^{\text {rd }} \text { Year } & & & & \\ 4^{\text {th }} \text { Year } & & & & \end{array}$

$* p>.05$ Not Significant

Table 8

Differences in the Levels of Sociability using t-Test

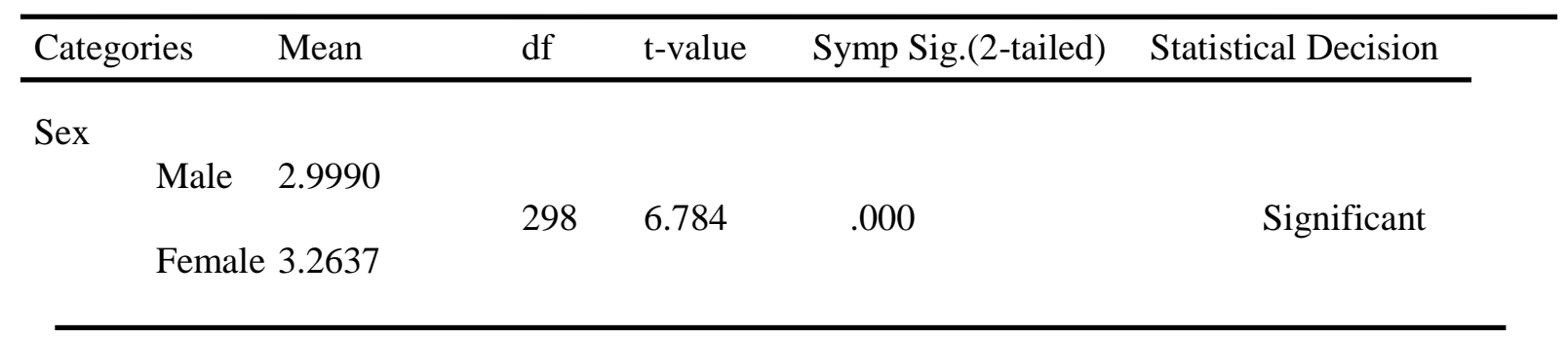

$*_{p}<.05$, Significant

Table 9

Differences in the Levels of Sociability using One-Way ANOVA

\begin{tabular}{lllll}
\hline Categories & df & F & Sig & Statistical Decision \\
\hline Course & & & & \\
BEED & & & & \\
BSED & & & & \\
& BS Infotech. 299 & 19.824 & .000 & Significant \\
BSHRST & & & & \\
BSIT & & & & \\
BCM . & & & &
\end{tabular}


Year Level
$1^{\text {st }}$ Year
$2^{\text {nd }}$ Year
$3^{\text {rd }}$ Year
299
40.206
.000
Significant
$4^{\text {th }}$ Year

$*_{p}<.05$ Significant

Table 10

Relationship Between Responses of the Students in Campus Activities that they Participated with, Extent of Students' Involvement and Levels of Sociability

\begin{tabular}{llll}
\hline $\begin{array}{l}\text { Source of Variation } \\
\text { Campus Activities that }\end{array}$ & Pearson's $r$ & 2 -tailed probability & Statistical Decision \\
\hline $\begin{array}{l}\text { Students Participated } \\
\text { with }\end{array}$ & & & \\
$\begin{array}{l}\text { Extent of Students' } \\
\text { Involvement }\end{array}$ & .878 & .001 & Significant \\
Level of Sociability & & & \\
$* p<.05$, Significant & & &
\end{tabular}

\section{Discussion}

The respondents often participated in campus activities when taken as an entire group while as to sex, the male responses were often while those of female were always. Willms, (2000), stated that most students participated in academic and non-academic activities at school to develop sense of belonging with their friends, have good relations with teachers and other students, and identify with and value schooling outcomes.

The Bachelor of Science in Elementary Education (BEEd), Bachelor of Science in Secondary Education (BSEd) and Bachelor of Caregiving Management (BCM) always participated, while BS Information Technology (BS Infotech) and Bachelor of Science in Hotel and Restaurant Technology (BSHRST) often participated while Bachelor of Science in Industrial Technology (BSIT) seldom participated in campus activities. The result explained the idea of Kuh (1995), which states that participation in extracurricular activities provides opportunities for students to apply classroom knowledge to real-world settings and develop skills that will assist in the practical realities of living after graduation.

As to year level, $1^{\text {st }}$ year and $2^{\text {nd }}$ year students always participated while $3^{\text {rd }}$ year and $4^{\text {th }}$ year seldom participated in campus activities. The results as cited by Burton (2001), could be done to the fact that college sponsored activities do not receive the full participation of all students despite the opportunities associated with extracurricular involvement.

In determining students' involvement in campus activities when taken as an entire group and when classified as to sex, course and year level, their responses were "always" or had a very high level of sociability. The result encompassed the idea of Astin (1993), which stated that having an active college social life by participating in college student organizations could influence how one perceives his or her own college experience. He added that students with more opportunities to involve in the overall student 
life of the institution could have more student-to-student interactions. Consequently, student interactions were found to cultivate a more active social life in college.

The levels of sociability as an entire group were very high. When classified as to sex, male were very high while those of female were high. As to course, the BEED, BSED,

BS Infotech and BCM were very high while those of BSHRST and BSIT were high. As to year level, $1^{\text {st }}$ year, $2^{\text {nd }}$ year and $4^{\text {th }}$ year were very high while $3^{\text {rd }}$ year were high. Significant differences existed when students were classified as to sex, course and year level. Baxter (1992), found that college sociability and affiliation cultivates students' intellectual development by initially teaching them responsibility and independence in regard to meeting new people who are becoming knowledgeable to the campus environment.

As to inferential statistics, $\mathbf{t}$-Test result showed that there was a significant difference in the responses in the campus activities participated in when respondents were classified as to sex because the $p$ value was less than 0.05 level of significance. This can be inferred with the idea of Trevino (1991), who found that extracurricular involvement was not significantly influenced by selected demographic data such as age, sex, GPA.

The One way ANOVA test revealed that significant difference existed in the campus activities that students participated in when classified as to course and year level, because the two-tailed probability was less than the set of .05 . This can be inferred to the idea of Abrahamowicz (1988), who cited by using the College Student Experiences Questionnaire (QSEC) to assess these variables, the study found that significant differences existed between the college experiences of undergraduate students who were members of organizations compared to students who were not.

Employing the t-test for independent samples, the result revealed that no significant differences existed in the extent of students' involvement in campus activities when they were classified as to sex, since the two-tailed probability was greater than the set of 0.05 level of significance. Baxter (1992), postulated that a student's learning and development were directly proportional to the quality and quantity of a student's involvement in the academic experience.

The One-way ANOVA test revealed that there was no significant difference existed in the students' involvement in campus activities when respondents were classified as to course and as to year level the two-tailed probability is greater than the set of .05 level of significance. Pascrella, 1991, cited that the greater the students involvement in college was the greater will be the amount of student learning and personal development.

There was positive and significant relationship in campus activities that student participated in, extent of students' involvement and levels of sociability. Terenzini, 1991, found out that when thinking in retrospect, college graduates perceived their extracurricular involvement as having substantial impact on the development of interpersonal and leadership skills important to general occupational success. Extracurricular activities involvement enhanced interpersonal and leadership skills, allowing students to explore their goals and to identify steps to achieve such goals.

\section{Conclusions}

In view of the findings, the following conclusions were deduced:

Almost every school offers some type of extracurricular activity, such as music, academic clubs, and sports. These activities offer opportunities for students to learn the values of teamwork, individual and group responsibility, physical strength and endurance, competition, diversity, and a sense of culture and community. Extracurricular activities provide a channel for reinforcing the lessons learned in the classroom, offering students the opportunity to apply academic skills in a real-world context, and are thus considered part of a well-rounded education.

Participation of students in various activities can be considered as meta-construct that includes behavioral, emotional and cognitive engagement. What makes participation unique is on how it can draw on the involvement in academic, social and extra-curricular activities and is considered crucial for improving positive academic outcomes. It must focus on the extent of positive reactions to teachers, students and the academic community. 
If, indeed, participation in extracurricular activities can lead to success in school, then the availability of these activities to students of all backgrounds becomes an important equity issue in background and school setting.

\section{Recommendations}

The West Visayas State University-Janiuay Campus must look into the responses of the respondents as to the campus activities that students participated in, their extent of involvement and levels of sociability in order to include in the campus calendar the activities that will maximize students' attendance and promote students' achievement.

There must be continued monitoring and evaluation of the campus activities that can increase the levels of sociability among students.

The administration must consider the conduct of activities with relevance to the students' welfare and must have promoted integral development among students.

The Office of Student Affairs must have encouraged students to become involved and stay involved in various campus activities. An effort to improve attendance in all campus activities of all students as an integral part of the larger school reform figure must also be given emphasis by the OSA.

Strong administrative support must be given in the conduct of relevant and enriching campus activities must also be given priority.

Further researches must be conducted in order to widen the perspectives along this line. If possible, variables not being studied must be taken into account to make this study more comprehensive and other dimensions of students' participation and its implications to levels of sociability must also be explained by future researchers.

\section{References}

Abrahamowics, D. (1988). College involvement, perceptions, and satisfaction: A study of membership in student organizations. Journal of College Student Development.

Astin, A.W. (1993). What matters in college? Four-critical years revisited. San Francisco: Jossey-Bass.

Baxter, M.(1992).Curricullar influences on college students'intellectual development. Journal of College Development.

Burton, M.D. (2001). Identifying potential participants for college extracurricular activities. College

Student Journal.

David, S. et al. How friendly are you? Sociability Test. www. Geocities.ws./paolaandsarah/ instructions.htm.

Garcia, F. (2003). Awareness on social studies program in public secondary schools in Bacolod City:

An evaluation (Unpublished dissertation). WVSU, Iloilo City.

Kuh, G.D. (1995). The other curriculum: Out-of-class experiences associated with student learning and personal development. Journal of Higher Education.

Pascarilla, E. et al. (2001). How college affects students. San Francisco: Jossey-Bass.

Trevino, J. (2002). Participation in ethnic/racial student organizations. University of California, Los

Angeles: Unpublished doctoral dissertation.

Willms, J.D. (2000). Student engagement at school a sense of belonging and participation. Organization for Eonomic Co-operation and Development (OECD) Journal. 


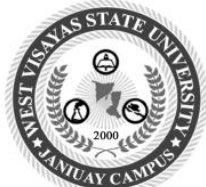

\section{West Visayas State University}

Janiuay Campus

Janiuay, Iloilo

\section{"Students' Involvement in Campus Activities: Implications to Levels of Sociability"}

A. Personal Information

Name: (Optional)

Year Level: Sex: Male Female

Course:

B. Instructions: Check the column that corresponds to your response in campus activities that you participate in:

\begin{tabular}{|c|c|c|c|c|}
\hline $\begin{array}{l}\text { As a student I participated in campus activities } \\
\text { like: }\end{array}$ & Never & Seldom & Often & Always \\
\hline 1. Accreditation & & & & \\
\hline 2. Acquaintance Party & & & & \\
\hline 3. Buwan ng Wika & & & & \\
\hline 4. BSIT Week & & & & \\
\hline 5. Cultural Night & & & & \\
\hline 6. English Festival & & & & \\
\hline 7. Foundation Day & & & & \\
\hline 8. Go-Green Program & & & & \\
\hline 9. Graduation Program & & & & \\
\hline 10.Hinampang & & & & \\
\hline 11. Holy Mass & & & & \\
\hline 12.Independence Day & & & & \\
\hline 13. IT Week & & & & \\
\hline 14. Literary Musical Contest & & & & \\
\hline 15.Nutrition Month & & & & \\
\hline 16.Orientation Program & & & & \\
\hline 17.Outreach Program & & & & \\
\hline 18.Paramedics Day & & & & \\
\hline 19.Recognition Program & & & & \\
\hline 20.Skills Olympics & & & & \\
\hline 21.Search for Miss and Mr. WVSU & & & & \\
\hline 22.U-Week & & & & \\
\hline 23.Valentines Day & & & & \\
\hline 24. World Teachers Day & & & & \\
\hline
\end{tabular}


C. Instructions: Check the column that corresponds to the frequency of your involvement in the campus activities.

\begin{tabular}{|c|c|c|c|c|}
\hline I involved in campus activities that.... & Never & Seldom & Often & Always \\
\hline 1. affect greatly my academic performance & & & & \\
\hline $\begin{array}{l}\text { 2. address my problems like low } \\
\text { achievement, high level of boredom and } \\
\text { alienation }\end{array}$ & & & & \\
\hline $\begin{array}{l}\text { 3. develop my emotional, cognitive and } \\
\text { social behaviors }\end{array}$ & & & & \\
\hline 4. discourage me from misbehaving & & & & \\
\hline $\begin{array}{l}\text { 5. promote my holistic development in my } \\
\text { life }\end{array}$ & & & & \\
\hline $\begin{array}{l}\text { 6. help accomplish my motivational needs } \\
\text { likes autonomy, competence and } \\
\text { relatedness }\end{array}$ & & & & \\
\hline 7. develops my sense of belonging & & & & \\
\hline 8. improves my leadership skills & & & & \\
\hline 9. are essential to my long term well-being & & & & \\
\hline $\begin{array}{l}\text { 10. open doors for other opportunities that will } \\
\text { help me become successful }\end{array}$ & & & & \\
\hline $\begin{array}{l}\text { 11. reinforce my high expectations for social } \\
\text { responsibilities }\end{array}$ & & & & \\
\hline $\begin{array}{l}\text { 12. help me familiarize with the learning } \\
\text { environment }\end{array}$ & & & & \\
\hline $\begin{array}{l}\text { 13. provide me with an avenue to meet my } \\
\text { future life-partner }\end{array}$ & & & & \\
\hline $\begin{array}{l}\text { 14. help me establish commonalities with } \\
\text { others and establish friendships }\end{array}$ & & & & \\
\hline $\begin{array}{l}\text { 15. provide me with rewarding and } \\
\text { challenging activities }\end{array}$ & & & & \\
\hline $\begin{array}{l}\text { 16. help promotes my feeling of support and } \\
\text { relatedness }\end{array}$ & & & & \\
\hline 17. motivate me to do well in school & & & & \\
\hline 18. make me proud of my school & & & & \\
\hline $\begin{array}{l}\text { 19. help me perceive that rules of school to be } \\
\text { enforced are fair }\end{array}$ & & & & \\
\hline $\begin{array}{l}\text { 20. helps my friends to look forward to go to } \\
\text { school }\end{array}$ & & & & \\
\hline 21. helps me participate in decision making & & & & \\
\hline 22. eases my feeling of loneliness & & & & \\
\hline $\begin{array}{l}\text { 23. help me feel that close to or valued by } \\
\text { teachers and school staff }\end{array}$ & & & & \\
\hline $\begin{array}{l}\text { 24. set standards and help us students to meet } \\
\text { it }\end{array}$ & & & & \\
\hline $\begin{array}{l}\text { 25. reinforce explicit expectations for our } \\
\text { positive behavior and academic success as } \\
\text { students }\end{array}$ & & & & \\
\hline $\begin{array}{l}\text { 26. create welcoming environment for us } \\
\text { students }\end{array}$ & & & & \\
\hline $\begin{array}{l}\text { 27. create common vision of success for us } \\
\text { students }\end{array}$ & & & & \\
\hline
\end{tabular}


28. creates trusting relationships among students, faculty and staff

29. provide opportunities for my involvement in productive roles

30. reinforce pro- social environment for us students

D. Directions: Please check the corresponding column that corresponds to your level of sociability.

\begin{tabular}{|c|c|c|c|c|}
\hline $\begin{array}{l}\text { Do you... } \\
\text { 1. like attending a lot to school activities? } \\
\text { 2. often need call friends to be with you during activities? }\end{array}$ & Never & Seldom & Often & Always \\
\hline $\begin{array}{l}\text { 3. talk a lot when you are together with friend during schoo } \\
\text { activities? }\end{array}$ & & & & \\
\hline 4. usually let yourself go and have a good time in school? & & & & \\
\hline $\begin{array}{l}\text { 5. like talking to people so much that you never miss out on } \\
\text { talking to a stranger? } \\
\text { 6. feel relaxed and self-confident in the company of other } \\
\text { people? }\end{array}$ & & & & \\
\hline 7. make friends easily with members of the same gender? & & & & \\
\hline 8. like mixing with lots of other people? & & & & \\
\hline 9. like to tell stories and jokes to groups of friends? & & & & \\
\hline $\begin{array}{l}\text { 10. enjoy talking and playing with other student of different } \\
\text { course? } \\
\text { 11. consider being liked by a wide range of people } \\
\text { important? }\end{array}$ & & & & \\
\hline $\begin{array}{l}\text { 12. spontaneously introduce yourself to stranger in social } \\
\text { gatherings? } \\
\text { 13. feel unhappy if you were prevented from making } \\
\text { numerous friends? }\end{array}$ & & & & \\
\hline $\begin{array}{l}\text { 14. usually prefer companions than to do things on your } \\
\text { own? }\end{array}$ & & & & \\
\hline 15. enjoy entertaining people? & & & & \\
\hline $\begin{array}{l}\text { 16. feel nervous whenever you have to approach a stranger } \\
\text { and ask for instructions or directions? }\end{array}$ & & & & \\
\hline 17. prefer reading than meeting new people? & & & & \\
\hline $\begin{array}{l}\text { 18. hate being in a crowd who play practical jokes to one } \\
\text { another? }\end{array}$ & & & & \\
\hline $\begin{array}{l}\text { 19. write down your inquiry rather than discuss it over the } \\
\text { phone? } \\
\text { 20. enjoy spending long periods of time by yourself? }\end{array}$ & & & & \\
\hline 21. feel distant and reserved than most people? & & & & \\
\hline $\begin{array}{l}\text { 22. consider it apprehensive about going to a venue full of } \\
\text { strange people? }\end{array}$ & & & & \\
\hline $\begin{array}{l}\text { 23. feel uncomfortable when people get close to you } \\
\text { physically? }\end{array}$ & & & & \\
\hline $\begin{array}{l}\text { 24. ever seriously felt that you would be happier living by } \\
\text { yourself in an island? }\end{array}$ & & & & \\
\hline $\begin{array}{l}\text { 25. rather spend an evening to an interesting person of your } \\
\text { own sex than being with a large crowd of friends? }\end{array}$ & & & & \\
\hline $\begin{array}{l}\text { 26. enjoy solitary things such as reading or watching tv on } \\
\text { your own? }\end{array}$ & & & & \\
\hline
\end{tabular}


27. inclined to avoid people whenever possible?

28. need people to approach you first before you converse with them?

29. inclined to limit your acquaintances to selected few?

30. feel ill at ease with people? 